\title{
PENINGKATAN HASIL BELAJAR SISWA SD PADA PEMBELAJARAN TEMATIK MELALUI PENERAPAN MODEL PEMBELAJARAN ROLE PLAYING
}

\author{
Fransiska Faberta Kencana Sari \\ 292015057@student.uksw.edu \\ Pendidikan Guru Sekolah Dasar - FKIP \\ Universitas Kristen Satya Wacana
}

\begin{abstract}
ABSTRAK
Penelitian ini bertujuan untuk meningkatkan hasil belajar siswa kelas IV di SD Negeri Kecandran 01 Kecamatan Sidomukti, Salatiga pada pembelajaran tematik tema 8.Daerah tempat tinggalku, subtema 1, pembelajaran ke 4 melalui penerapan model pembelajaran role playing. Jenis penelitian ini adalah penelitian tindakan mengadopsi model Stringer dengan pelaksanaan tahap look (melihat), think (berpikir) dan act (bertindak). Subjek penelitian ini adalah siswa kelas IV SD Negeri Kecandran 01 sebanyak 33 siswa yang terdiri dari 16 siswa laki-laki dan 17 siswa perempuan. Pengumpulan data dilakukan melalui penilaian autentik dengan menilai sikap (observasi), pengetahuan (tes), dan keterampilan (penilaian kinerja). Analisis data dilakukan dengan menggunakan analisis deskriptif komparatif yaitu membandingkan kondisi awal sebelum tindakan dengan hasil setelah tindakan. Hasil penelitian menunjukkan peningkatan hasil belajar dalam ranah pengetahuan, sikap dan keterampilan. Dalam ranah pengetahuan hasil belajar meningkat dari persentase ketuntasan 48\% dengan rata-rata kelas 67, menjadi 93\% dengan rata-rata kelas 85 . Dalam ranah sikap rata-rata siswa mampu mencapai predikat B (Baik) dari predikat C (Cukup). Dalam ranah keterampilan hasil belajar meningkat dari rata-rata 62 menjadi 75. Sehingga dapat disimpulkan penerapan model pembelajaran role playing dapat meningkatkan hasil belajar pada pembelajaran tematik kerena mampu meningkatkan hasil belajar siswa dalam tiga ranah yaitu pengetahuan, sikap dan keterampilan.
\end{abstract}

Kata Kunci: Role Playing, Hasil Belajar, Pembelajaran Tematik

\section{PENDAHULUAN}

Mulai tahun pelajaran 2013/2014 Pemerintah telah memberlakukan kurikulum baru yang disebut Kurikulum 2013 bagi sekolah yang ditunjuk menjadi sekolah sasaran (Direktorat Pembinaan Sekolah Dasar, 2016). Kurikulum 2013 merupakan penyempurnaan dari Kurikulum Berbasis Kompetensi (KBK) dan Kurikulum Tingkat Satuan Pendidikan (KTSP) yang melakukan penyederhanaan tematikintegratif dan memiliki tujuan untuk mempersiapkan manusia Indonesia agar memiliki kemampuan hidup sebagai pribadi dan warga negara yang beriman, produktif, kreatif, inovatif, dan afektif serta mampu berkonstribusi pada kehidupan bermasyarakat, berbangsa bernegara, dan peradaban dunia (Slameto, 2015:4). Adapun pada tahun pelajaran 2016/2017 melalui SK Direktur Pendidikan Dasar dan Menengah Nomor.253/Kep.D/KR/2017 pemerintah menetapkan sejumlah 25\%, sekolah harus menerapkan Kurikulum 2013, berlanjut pada tahun pelajaran 2017/2018 sebanyak $60 \%$, hingga pada tahun pelajaran 2019/ 2020 mencapai 100\%. Pemberlakukan 
Kurikulum 2013 untuk SD/MI secara nasional mulai membawa berbagai konsekuensi. Konsekuensi utama pemberlakuan kurikulum 2013 tersebut diantaranya pada cara mensinergikan pendekatan, model dan standar proses pembelajaran, serta cara menyusun dan melakukan penilaian. Hal ini dikarenakan ruh implementasi kurikulum 2013 adalah pembelajaran yang dirancang dengan seksama, berdasarkan pengorganisasian materi yang dilakukan dengan menggunakan model tematik integratif, disinergikan dengan model-model pembelajaran inovatif, dan dilakukan penilaian dengan model penilaian autentik (Mawardi, 2014:107-108).

SD Negeri Kecandran 01 merupakan salah satu sekolah dasar di Kecamatan Sidomukti, Kota Salatiga yang telah menerapkan kurikulum 2013 pada kelas I dan IV mulai tahun pelajaran 2016/2017. Berdasarkan observasi pada tanggal 28 Maret 2017 terkait hasil belajar siswa kelas IV, dalam ranah pengetahuan diperoleh data bahwa 16 dari 33 siswa belum mencapai KKM yang ditentukan yaitu 70, dengan rata-rata nilai kelas 67. Adapun dalam ranah sikap rata-rata siswa mendapat predikat C (Cukup). Dalam ranah keterampilan rata-rata siswa mendapatkan nilai 62 . Setelah menganalisis melalui keterlibatan secara langsung dalam proses pembelajaran di kelas dan wawancara, diperoleh data bahwa guru kelas IV SD Negeri Kecandran 01 sudah menerapkan berbagai model pembelajaran, salah satunya model pembelajaran role playing. Namun, penerapan model pembelajaran role playing yang diselenggarakan guru belum sesuai sintaks/ langkah-langkah yang sesuai dalam model pembelajaran role playing. Dimana tidak terdapat langkah/sintaks untuk menata panggung melaksanakan permainan peran ulang, diskusi dan evaluasi kedua serta berbagi pengalaman. Sehingga, pengalaman belajar yang seharusnya didapatkan siswa melalui kegiatan tersebut belum dimiliki oleh siswa. Guna memperbaiki model pembelajaran yang sudah diterapkan oleh guru kelas IV di SD Negeri Kecandran 01 yaitu pada pembelajaran dengan model role playing, peneliti mencoba memberikan penerapan model role playing dalam proses pembelajaran sesuai dengan sintak yang tepat yang pada akhirnya diharapkan mampu meningkatkan hasil belajar siswa.

\section{TINJAUAN PUSTAKA}

\section{Model Pembelajaran Role playing}

Menurut Mawardi (2018:29) model pembelajaran merupakan kerangka konseptual untuk merancang dan melaksanakan pembelajaran, mengorganisasikan pengalaman belajar untuk mencapai tujuan, dan sebagai pedoman dalam proses pembelajaran karena berisi sintaks pembelajaran yang sistematis. Pengertian model pembelajaran sebagai kerangka konseptual dalam pembelajaran sepemikiran dengan pengertian model pembelajaran menurut Kunandar (2014:65) yang menguraikan bahwa model pembelajaran merupakan kerangka konseptual atau pola yang digunakan sebagai pedoman dalam merencanakan dan mewujudkan suatu proses pembelajaran di kelas yang mengarahkan pendidik dalam mendesain pembelajaran untuk membelajarkan siswa sehingga tujuan pembelajaran tercapai. Jadi dapat disimpulkan bahwa model pembelajaran merupakan kerangka konseptual yang berisi langkah-langkah (sintaks) kegiatan pembelajaran yang 
berperan sebagai pedoman dalam mengorganisasikan pengalaman belajar untuk mencapai tujuan pembelajaran.

Adapun guru yang efektif akan menerapkan model-model pembelajaran untuk memecahkan masalah (Huda, 2015:76). Menurut Joyce (Huda, 2015:74) terdapat empat kelompok model pembelajaran yang didasarkan pada sifat, karakteristik, dan pengaruhnya diantaranya model-model memproses informasi, modelmodel personal, model-model interaksi sosial, dan model-model perubahan perilaku. Adapun model pembelajaran role playing merupakan salah satu model dalam kelompok model-model interaksi sosial.

Model pembelajaran role playing merupakan salah satu model pembelajaran interaksi sosial yang menyediakan kesempatan kepada siswa untuk melakukan kegiatan-kegiatan belajar secara aktif melalui personalisasi dengan cara memberi- kan peran-peran tertentu kepada siswa dan mendramatisasikan peran tersebut kedalam sebuah pentas (Setiawati, 2011:231). Role playing berfungsi untuk 1) mengeksplorasi perasaan siwa, 2) mentransfer dan mewujudkan pandangan mengenai perilaku, nilai, dan persepsi siswa, 3) mengem-bangkan skill pemecahan masalah dan tingkah laku, 4) mengeksplorasi materi pembelajaran dengan cara yang berbeda (Sinanglingtyas, 2013:2). Menurut Mawardi (2017: 33) terdapat empat aspek umum dalam struktur implementasi tiaptiap model pembelajaran diantaranya sintak, sistem sosial, tugas/peran guru, dan pengaruh model.

a) Sintak

Dalam penerapannya model pembelajaran role playing terdiri dari beberapa sintaks (langkahlangkah kegiatan) yang secara rinci disajikan dalam tabel berikut:

Tabel 1. Langkah-langkah Penerapan Model Pembelajaran Role playing

\begin{tabular}{ll}
\hline \multicolumn{1}{c}{$\begin{array}{c}\text { Langkah-Langkah/ } \\
\text { Sintaks Pembelajaran }\end{array}$} & \multicolumn{1}{c}{ Keterangan } \\
\hline Pemanasan (Warming Up) & $\begin{array}{l}\text { Pada langkah ini guru mengenalkan siswa pada suatu } \\
\text { permasalahan dengan membacakan cerita atau } \\
\text { mengajukan pertanyaan pancingan yang membuat } \\
\text { siswa memikirkan masalah tersebut. }\end{array}$ \\
\hline Memilih Pemain (Partisipan) & $\begin{array}{l}\text { Pada langkah ini siswa dan guru membahas karakter } \\
\text { pemain dan menentukan siapa yang akan memainkan } \\
\text { peran. }\end{array}$ \\
\hline Menata Panggung & $\begin{array}{l}\text { Pada langkah ini guru mendiskusikan dengan siswa } \\
\text { dimana dan bagaimana peran itu akan dimainkan. }\end{array}$ \\
\hline Menyiapkan Pengamat (Observer) & $\begin{array}{l}\text { Pada langkah ini siswa yang tidak memainkan peran } \\
\text { diminta sebagai pengamat permainan. }\end{array}$ \\
\hline Memainkan Peran/Manggung & $\begin{array}{l}\text { Pada langkah ini siswa yang telah mendapat peran } \\
\text { memainkan perannya. }\end{array}$ \\
\hline Diskusi dan Evaluasi & $\begin{array}{l}\text { Pada langkah ini guru membimbing siswa } \\
\text { mengevaluasi hasil permainan peran. }\end{array}$ \\
\hline Memainkan Peran Ulang/Manggung Ulang & $\begin{array}{l}\text { Pada langkah ini jika masih ada siswa yang belum } \\
\text { mengerti atau masih banyak kesalahan, maka } \\
\text { permainan peran diulang. }\end{array}$ \\
\hline Diskusi dan Evaluasi ke Dua & $\begin{array}{l}\text { Pada langkah ini mengevaluasi permainan siswa ke- } \\
2 .\end{array}$ \\
\hline
\end{tabular}


- Pada langkah ini guru bersama siswa mengambil kesimpulan dari permainan yang telah dilakukan.

- Guru memberikan penguatan dengan tujuan siswa memahami nilai-nilai yang diharapkan diperoleh siswa melalui bermain peran.

- Siswa dan guru menghubungkan situasi yang diperankan dengan kehidupan di dunia nyata dan masalah-masalah lain yang akan muncul. b) Sistem sosial

Sistem sosial mendeskripsikan peran dan relasi antara guru dan siswa. Pada molel pembelajaran role playing guru memiliki tanggung jawab untuk memberikan penjelasan aturan permainan peran secara rinci, dan membimbing siswa melalui aktivitas dalam tiap tahap. Adapun situasi kelas pada saat model pembelajaran berlangsung yaitu seperti pada saat menonton sebuah pertunjukan drama. Dimana siswa terbagi menjadi dua yatu siswa yang bertugas sebagai pemain peran serta siswa yang bertugas sebagai peng-amat dimana mereka mengamati permainan peran yang sedang dimankan. Adapun relasi yang diharapkan tumbuh antar siswa yaitu saling menghargai dan tanggung jawab. Siswa yang bertugas sebagai pemain peran memerankan peran dengan tanggung jawab, siswa yang bertugas sebagai pengamat menghargai siswa yang sedang bermain peran dengan memperhatikan permainan peran dan dengan tanggung jawab mencatat hal penenting berdasarkan permainan peran yang ditampilan pada lembar kerja siswa yang telah ditugaskan oleh guru. Setiap siswa memiliki peran dalam proses pembelajaran, sehingga setiap siswa aktif terlibat dalam proses pembelajaran.

c) Tugas/Peran Guru

Tugas/peran guru mendesripsikan bagaimana seseorang guru harus merespon apa yang dilakukan siswa. Menurut Huda (2015: 118) terdapat lima peran penting guru dalam pembelajaran dengan model role playing yaitu: 1) Guru menerima pendapat dan saran siswa, 2) Guru membimbing siswa mengkaji suatu permasalahan tertentu, memperhitungkan dan mempertimbangkan alternatif yang muncul dari sudut pandang yang berbeda, 3) Memfasilitasi siswa dalam merefleksikan, menceritakan kembali, dan merangkum sebuah konsep untuk dapat meningkatkan kesadaran siswa mengenai pemikiran mereka sendiri, 4) Guru perlu menitik beratkan bahwa terdapat beberapa cara berbeda untuk memainkan peran yang sama, 5) Guru menegaskan bahwa terdapat banyak cara alternatif untuk memecahkan masalah.

d) Sistem Dukungan

Mendeskripsikan kondisi-kondisi mendukung yang seharusnya diciptakan guru pada model tertentu. 
Perangkat utama dalam model pembelajaran role playing yaitu situasi permasalahan yang berperan dalam membentuk dan mengarahkan peran. Situasi permasalahan dapat memfasilitasi penggambaran peran atau perasaan masing-masing karakter yang harus dipertunjukkan oleh masing-masing siswa. Referensi dalam menemukan situasi permasalahan dapat bersumber dari cerpen, novel atau film. Diperlukan pula alat/media berupa kostum dan peralatan lainnya yang mendukung siwa dalam permainan peran.

e) Pengaruh

Mengarah pada efek-efek yang ditimbulkan oleh setiap model. Menurut Joyce (Mawardi, 2017:30) pengaruh atau yang disebut Instruction and natural effect merupakan hasil belajar yang diperoleh secara langsung berdasarkan rancangan tujuan pembelajaran yang telah ditetapkan (dampak instruksional) dan dampak hasil belajar yang mengiringi di luar tujuan yang telah ditetapkan (dampak pengiring). Adapun Huda (2015:120) menjelaskan tentang dampak pengiring yang diharapkan dimunculkan dalam diri siswa melalui pembelajaran model role playing diantaranya 1) Mampu menganalisis nilai dan perilaku masing-masing, 2) mengembangkan strategi-strategi pemecahan masalah interpersonal ataupun personal, 3) Meningkatkan rasa empati terhadap orang lain, 4)
Memperoleh informasi mengenai masalah dan norma sosial sekitar.

Selanjutnya terdapat beberapa penelitian terdahulu yang telah membuktikan bahwa model pembelajaran role playing mampu meningkatkan hasil belajar siswa diantaranya, penelitian dengan judul "Penerapan Model Pembelajaran Role playing Pada Mata Pelajaran IPA untuk Meningkatkan Hasil Belajar Siswa Kelas IV Semester I SD N Wonokerto 1 Karangtengah Demak Tahun Ajaran 2011/2012" yang dilakukan oleh Djario dkk (2012) dengan hasil peningkatan persentase ketuntasan belajar dari 31,43\%, dengan rata-rata kelas 5,57 meningkat mencapai $77,14 \%$ dengan nilai rata-rata kelas mencapai 7,27. Terdapat pula penelitian dengan judul "Upaya Meningkatkan Nilai-Nilai Karakter Peserta Didik Melalui Penerapan Metode Role playing" oleh Kirorim Baroroh dengan hasil penelitian menunjukkan terjadinya peningkatan nilai-nilai karakter yang dapat dilihat dari indikator disiplin, kerja keras, kreatif, dan kemampuan komunikasi. Kenaikan terbesar terjadi pada nilai kreatif $(19,6 \%)$, pada kemampuan komunikasi terjadi peningkatan sebesar 18,9\%. Pada indikator disiplin terjadi kenaikan sebesar $10,9 \%$. Indikator kerja keras masih berada di urutan paling bawah dalam peningkatan masing-masing indikator karakter yang menunjukkan kenaikan 7,4\%. Adapun kelebihan dalam penelitian tindakan yang akan peneliti lakukan dibandingkan dengan penelitian terdahulu yaitu meningkatkan hasil belajar pada pembelajaran tematik yang mencakup tiga ranah yaitu pengetahuan, sikap dan keterampilan (Permendikbud No. 23 Tahun 2016). 


\section{Hasil Belajar}

Hasil belajar merupakan kemampuan-kemampuan yang dimiliki siswa setelah menerima pengalaman belajar, dan merupakan kemampuan yang diperoleh siswa setelah mengalami proses belajar (Sudjana, 2006:22).

Menurut Kemendikbud (2016: 14) terdapat beberapa istilah yang berhubungan dengan hasil belajar diantaranya 1) Penilaian, merupakan proses mengumpulkan dan mengolah informasi guna mengukur pencapaian hasil belajar siswa, 2) Teknik penilaian, merupakan cara yang digunakan pendidik untuk melakukan penilaian dan menggunakan bebagai bentuk instrument penilaian, 3) Instrumen penilaian, alat yang disusun dan digunakan untuk mengumpulkan dan mengolah informasi untuk mengukur pencapaian hasil belajar siswa, 4) Kriteria Ketuntasan Minimal (KKM) merupakan kriteria ketuntasan belajar yang ditentukan satuan pendidikan dengan mengacu pada standar kompetensi lulusan, serta mempertimbangkan karakteristik siswa, karakteristik mata pelajaran dan kondisi satuan pendidikan. Adapun dalam Permendikbud No. 23 Tahun 2016 tentang Standar Penilaian Pendidikan dijabarkan bahwa penilaian hasil belajar merupakan proses pengumpulan informasi/data tentang capaian pembelajaran siswa dalam kompetensi ranah sikap, pengetahuan dan keterampilan yang dilakukan secara terencana dan sistematis selama dan setelah proses pembelajaran. Maka dapat disimpulkan bahwa hasil belajar merupakan capaian kompetensi siswa yang dapat diukur selama dan setelah proses pembelajaran dengan lingkup penilaian hasil belajar mencakup ranah sikap, pengetahuan dan keterampilan.

Menurut Mawardi (2014:117) penilaian hasil belajar yang disarankan dalam Kurikulum 2013 adalah penilaian autentik. Istilah autentik merupakan sinonim dari asli, nyata, reliabel, atau valid. Dalam penilaian autentik digunakan alat ukur yang bermakna signifikan atas hasil belajar siswa untuk ranah sikap, pengetahuan dan keterampilan. Dalam Kemendikbud (2016: 6-13) dijabarkan bahwa 1) Penilaian sikap merupakan penilaian terhadap perilaku siswa meliputi penilaian sikap spiritual dan sosial. Penilaian sikap menggunakan teknik observasi melalui wawancara, catatan anekdot dan catatan kejadian tertentu sebagai penilaian utama. Serta penilaian diri serta penilaian antar teman sebagai teknik penilaian penunjang, 2) Penilaian pengetahuan merupakan penilaian terhadap pengetahuan siswa secara intelektual. Teknik penilaian pengetahuan melalui tes tertulis, lisan dan penugasan. Hasil penilaian pengetahuan dilaporkan dalam bentuk angka, predikat dan deskripsi. Angka menggunakan retang nilai 0-100. Predikat disajikan dalam bentuk A, B, C, D dengan rentang predikat ditentukan oleh satuan pendidikan berdasarkan pertimbangan KKM, 3) Penilaian keterampilan merupakan kegiatan untuk mengukur kemampuan siswa dalam menerapkan pengetahuan dalam melaksanakan tugas tertentu. Teknik penilaian keterampilan menggunakan dengan teknik penilaian kinerja, proyek, dan portofolio. Penilaian keterampilan menggunakan angka, predikat dan deskripsi. Adapun rentang angka 0-100. 


\section{Pembelajaran Tematik}

Menurut Mawardi (2014:109) pembelajaran tematik integratif merupakan pembelajaran yang menggunakan tema sebagai pemersatu kegiatan pembelajaran dengan memadukan beberapa mata pelajaran sekaligus dalam satu kali tatap muka. Pembelajaran tematik terpadu berfungsi untuk memberikan kemudahan bagi siswa dalam memahami dan mendalami konsep materi yang tergabung dalam tema serta mampu menambah semangat belajar karena materi yang dipelajari merupakan materi yang kontekstual dan bermakna bagi siswa. Adapun ciri-ciri pembelajaran tematik terpadu: a) pemisahan antar muatan pelajaran tidak begitu jelas (menyatu dalam satu pemahaman dalam kegiatan); b) berpusat pada siswa; c) memberikan pengalaman langsung pada siswa; d) Menyajikan konsep dari berbagai pelajaran dalam satu proses pembelajaran;

e) bersifat luwes dengan adanya keterpaduan berbagai muatan pelajaran; f) hasil pembelajaran dapat berkembang sesuai dengan minat dan kebutuhan anak melalui penilaian proses dan hasil belajarnya. Jadi pembelajaran tematik terpadu merupakan pembelajaran bermakna yang terdiri dari beberapa mata pelajaran yang diikat oleh suatu tema tertentu. Siswa akan mempelajari beberapa muatan mata pelajaran dalam setiap pembelajaran. Dalam satu kali tatap muka atau satu pembelajaran, siswa akan belajar materi berdasarkan tema yang dibagi dalam beberapa subtema dimana setiap subtema dialokasikan dalam waktu satu minggu, yaitu pembelajaran satu hingga pembelajaran enam. Jadi satu pembelajaran dialokasikan dalam waktu satu hari.

\section{METODE}

Penelitian ini menggunakan jenis Penelitian Tindakan dengan mengadopsi model Stringer yang membagi prosedur penelitian menjadi tiga tahap yaitu look (melihat), think (berpikir), dan act (bertindak) (Yaumi, 2014:41). Penelitian ini dilaksanakan pada semester II tahun ajaran 2016/2017 tepatnya pada bulan Maret-April 2017 di SD Negeri Kecandran 01 Kecamatan Sidomukti, Kota Salatiga. Subjek dalam penelitian ini adalah siswa kelas IV SD Negeri Kecandran 01 sejumlah 33 siswa dengan 16 siswa lakilaki dan 17 siswa perempuan. Terdapat dua variabel dalam penelitian ini yaitu model pembelajaran role playing sebagai variabel bebas dan hasil belajar dalam pembelajaran tematik tema 8 sebagai variabel terikat. Adapun pengumpulan data pada penelitian ini menggunakan 1) Pedoman wawancara dan lembar observasi, guna mengetahui kendala yang dihadapi oleh siswa dan guru selama proses pembelajaran, 2) Tes, guna mengukur hasil belajar siswa (pengetahuan), 3) Rubrik penilaian (sikap dan keterampilan). Dalam penelitian ini menggunakan teknik analisis data secara deskriptif komparatif yaitu dengan membandingkan kondisi awal sebelum tindakan dengan hasil belajar setelah pemberian tindakan.

\section{HASIL DAN PEMBAHASAN}

\section{Hasil Penelitian}

Berdasarkan observasi di SD Negeri Kecandran 01 pada tanggal 28 Maret 2017, terkait dengan hasil belajar siswa kelas IV pada tema 8. Daerah Tempat Tinggalku, subtema 1, Lingkungan 
Tempat Tinggalku, pembelajaran 1 dalam ranah pengetahuan diperoleh data bahwa 16 dari 33 siswa belum mencapai KKM yang ditentukan yaitu 70 . Dengan nilai rata-rata kelas yaitu 67, dengan nilai tertinggi 80 dan nilai terrendah 45. Adapun hasil belajar ranah sikap mencapai predikat C (Cukup) dan ranah keterampilan mencapai rata-rata 62 .

Setelah menganalisis melalui keterlibatan secara langsung dalam proses pembelajaran di kelas dan wawancara diperoleh hasil bahwa guru sudah menerapkan berbagai model pembelajaran, salah satunya model pembelajaran role playing. Namun, penerapan model pembelajaran role playing, yang dilakukan guru belum sesuai sintaks/langkah-langkah yang sesuai dalam model role playing. Dimana tidak terdapat langkah/sintaks untuk menata panggung, melaksanakan permainan peran ulang, diskusi dan evaluasi kedua serta berbagi pengalaman. Sehingga pengalaman belajar yang seharusnya didapatkan siswa melalui kegiatan tersebut belum dimiliki oleh siswa.

Selanjutnya dilakukan tahap bertindak (act), dimulai dengan mempersiapkan Rencana Pelaksanaan Pembelajaran (RPP) tema 8. Daerah Tempat Tinggalku, subtema 1, Lingkungan Tempat Tinggalku, pembe-lajaran 4 yang berisi muatan mata pelajaran PPKn, Bahasa Indonesia dan IPS. Selanjutnya dilaksanakan tahap pelaksanaan kegiatan belajar mengajar pada hari Jumat, 1 April 2017 pukul 07.45 -11.00 WIB. Adapun pelaksanaan pembelajaran yaitu yaitu guru mengawali dengan memberikan salam dan menyapa siswa, siswa berdoa dipimpin oleh ketua kelas. Kemudian guru mengecek kehadiran siswa dan melakukan "Tepuk Semangat" bersama. Guru membangun apresiasi dengan menampilkan foto presiden dan wakil presiden apakah ada perbedaan dari segi fisiknya, kemudian guru meminta siswa untuk mengamati teman sebangku, siswa menemukan perbedaan dari temantemannya, guru memberikan penegasan bahwa walupun terdapat keberagaman ciri fisik siswa harus dapat menghargai satu dengan yang lainya. Guru menjelaskan tema, subtema dan pembelajaran serta tujuan pembelajaran yang akan dilaksanakan.

Kegiatan inti dimulai dengan sintaks ke- I Pemanasan (Warming Up) yaitu guru mengajukan pertanyaan pancingan seperti "Apakah keberagaman individu hanya terlihat dari ciri fisiknya?", Guru menjelaskan bahwa untuk mengetahui keberagaman karakteristik individu, siswa akan bermain peran. Kemudian Siswa mendengarkan penjelasan guru tentang kegiatan bermain peran tentang kisah 5 Bersaudara dan siswa bersamasama membaca dialog kisah 5 Bersaudara yang diberikan oleh guru. Sintaks ke-II Memilih Pemain (Partisipan) yaitu guru menentukan siswa yang akan memainkan peran 5 Bersaudara melalui undian dan Siswa bertanya jawab dengan guru terkait hal-hal yang belum dimengerti tentang peran yang akan dimainkan. Sintaks ke-III Menata Panggung yaitu guru mendiskusikan dengan siswa dimana dan bagaimana peran itu akan dimainkan dan siswa dan guru mempersiapkan apa saja kebutuhan yang diperlukan. Sintaks ke-IV Menyiapkan Pengamat (Observer) yaitu guru menjelaskan mengenai siswa yang tidak ikut berperan, bertugas sebagai pengamat dan mengisi LKS serta menata 
panggung kemudian guru membimbing siswa dalam berlatih selama 10 menit. Sintaks ke-V Memainkan Peran (Manggung) yaitu siswa mulai bermain peran 5 bersaudara kemudian siswa sebagai pengamatan menulis tokoh dan sifat-sifatnya. Sintaks ke-VI Diskusi dan Evaluasi yaitu guru dan siswa mendiskusikan permainan peran tadi dan melakukan evaluasi terhadap peran-peran yang dilakukan. Sintaks ke-VII Memainkan Peran Ulang (Manggung Ulang) yaitu siswa yang bertugas sebagai pemain peran memerankan ulang adegan yang belum dipahami oleh pengamat mengenai cerita 5 bersaudara. Sintaks ke-VIII Diskusi dan Evaluasi Kedua yaitu siswa mendiskusikan tentang tokoh dalam kisah 5 Bersaudara untuk menemukan contoh keberagaman karak-teristik individu berdasarkan sifat. Sintaks ke-IX Berbagi Pengalaman dan Kesimpulan yaitu siswa sebagai pengamat mempresentasikan secara lisan mengenai tokoh dan sifat yang telah diperankan didepan kelas secara lisan, siswa diajak untuk berbagi pengalaman sebagai pemain peran dalam kisah 5 Bersaudara. Kemudian guru menjelaskan bahwa terdapat tokoh mbok yem yang menghasilkan jasa, guru mengarahkan siswa mempelajarai kegiatan ekonomi seperti kegiatan produksi, konsumsi dan distribusi yang ada di Salatiga.

Kegiatan inti selanjutnya yaitu sintaks ke-I Pemanasan (Warming $U p$ ) yaitu guru menstimulus ide gagasan dan motivasi siswa dengan mengajukan pertanyaan "Di mana kamu tinggal?, Di pulau manakah kota tempat tinggalmu berada?", guru mengajak siswa bertanya jawab mengenai nama pulau di wilayah negara Indonesia menggunakan peta Provinsi
Jawa Tengah. Kemudian siswa mengamati peta Pulau Jawa Tengah dan melingkari kota Salatiga, siswa membaca narasi mengenai kegiatan ekonomi dan macammacamnya. Sintaks ke-II Memilih Pemain (Partisipan) yaitu guru membagi siswa kedalam 3 kelompok secara heterogen kemudian siswa mengambil undian untuk menentukan kelompok produksi, distribusi dan konsumsi. Guru menjelaskan bahwa setiap kelompok akan memainkan peran sesuai dengan undian yang didapat dan siswa bertanya jawab dengan guru terkait hal-hal yang belum dimengerti tentang peran yang akan dimainkan. Sintaks ke-III Menata Panggung yaitu guru berdiskusi dengan siswa bahwa bermain peran dimainkan di depan kelas dan secara bergantian dimulai dari produksi, distribusi dan konsumsi kemudian siswa dan guru mempersiapkan kebutuhan yang diperlukan serta guru membimbing menata panggung dan berlatih bermain peran selama 15 menit. Sintaks ke-IV Menyiapkan Pengamat (Observer) yaitu guru menjelaskan bahwa siswa yang tidak sedang bermain peran bertugas sebagai pengamat kemudian guru memberikan Lembar Kerja Siswa (LKS) terhadap pengamat agar dapat terlibat secara aktif dalam permainan peran tersebut. Sintaks ke V Memainkan Peran (Manggung) yaitu siswa bermain peran tentang kegiatan produksi, distribusi dan konsumsi, siswa yang tidak bermain peran bertugas sebagai pengamat mencatat hal-hal penting di Lembar Kerja Siswa (LKS) kemudian guru memberikan arahan jika cerita mulai bergeser jauh. Sintaks ke-VI Diskusi dan Evaluasi yaitu guru bersama siswa mendiskusikan permainan peran tadi dan melakukan evaluasi terhadap peran-peran 
yang dilakukan. Sintaks ke-VII Memainkan Peran Ulang (Manggung Ulang) yaitu siswa yang bertugas sebagai pemain peran memerankan ulang kegiatan produksi, distribusi atau konsumsi pada bagian yang belum dipahami siswa lain sebagai pengamat. Sintaks ke-VIII Diskusi dan Evaluasi Kedua yaitu Siswa mendiskusikan tentang kegiatan produksi, distribusi dan konsumsi dengan guru bertanya kepada pengamat bagaimana kegiatan produksi, distribusi dan konsumsi yang sudah ditampilkan dalam kegiatan bermain peran. Sintaks ke-IX Berbagi Pengalaman dan Kesimpulan yaitu siswa diajak untuk berbagi pengalaman sebagai pemain dalam kegiatan produksi, distribusi dan konsumsi, guru memberikan penegasan dengan menjelaskan tentang kegiatan ekonomi dan macam-macam kegiatannya yaitu produksi, distribusi dan konsumsi. Kemudian Siswa mengerjakan evaluasi berupa tes tertulis (pilihan ganda) dan megumpulkan pekerja-annya.

Guru mengakhiri pembelajaran dengan siswa mengumpulkan Lembar Kerja Siswa ke depan kelas kemudian siswa beserta guru melakukan refleksi dan menyimpulkan materi pembelajaran. Guru memberikan bintang kepada kelompok terkompak saat proses pembelajaran serta guru memberikan pesan moral. Kemudian ketua kelas menutup dengan doa dan salam penutup. Setelah melakukan pengukuran terhadap tes tertulis yang dikerjakan siswa diperoleh hasil yaitu persentase ketuntasan mencapai 93\% (terdapat 2 siswa yang belum mencapai KKM), nilai rata-rata kelas 85 dengan nilai tertinggi 100 dan nilai terendah 65 .

Tabel 2. Perbandingan Hasil Belajar Siswa (Ranah Pengetahuan) Sebelum dengan Setelah Tindakan

\begin{tabular}{|l|c|c|}
\hline \multicolumn{1}{|c|}{ Keterangan } & Sebelum Tindakan & Setelah Tindakan \\
\hline Tuntas & 17 & 31 \\
\hline Tidak Tuntas & 16 & 2 \\
\hline Nilai Terendah & 45 & 65 \\
\hline Nilai Tertinggi & 80 & 100 \\
\hline Rata-Rata Kelas & 67 & 85 \\
\hline Persentase Ketuntasan & $48 \%$ & $93 \%$ \\
\hline
\end{tabular}

(Sumber: Data Primer Nilai Siswa)

Selanjutnya melalui uji one sample $T$ test terhadap hasil belajar dalam ranah pengetahuan dengan menggunakan SPSS 20 didapat hasil sebagai berikut:

Tabel 3. Hasil Uji One Sample T Test

One-Sample Test

\begin{tabular}{|c|c|c|c|c|c|c|}
\hline & \multicolumn{6}{|c|}{ Test Value $=0$} \\
\hline & \multirow[t]{2}{*}{$\mathrm{T}$} & \multirow[t]{2}{*}{ Df } & \multirow[t]{2}{*}{$\begin{array}{l}\text { Sig. (2- } \\
\text { tailed) }\end{array}$} & \multirow[t]{2}{*}{$\begin{array}{c}\text { Mean } \\
\text { Difference }\end{array}$} & \multicolumn{2}{|c|}{$\begin{array}{l}95 \% \text { Confidence Interval of } \\
\text { the Difference }\end{array}$} \\
\hline & & & & & Lower & Upper \\
\hline 2 & 46.768 & 65 & .000 & 75.833 & 72.60 & 79.07 \\
\hline
\end{tabular}



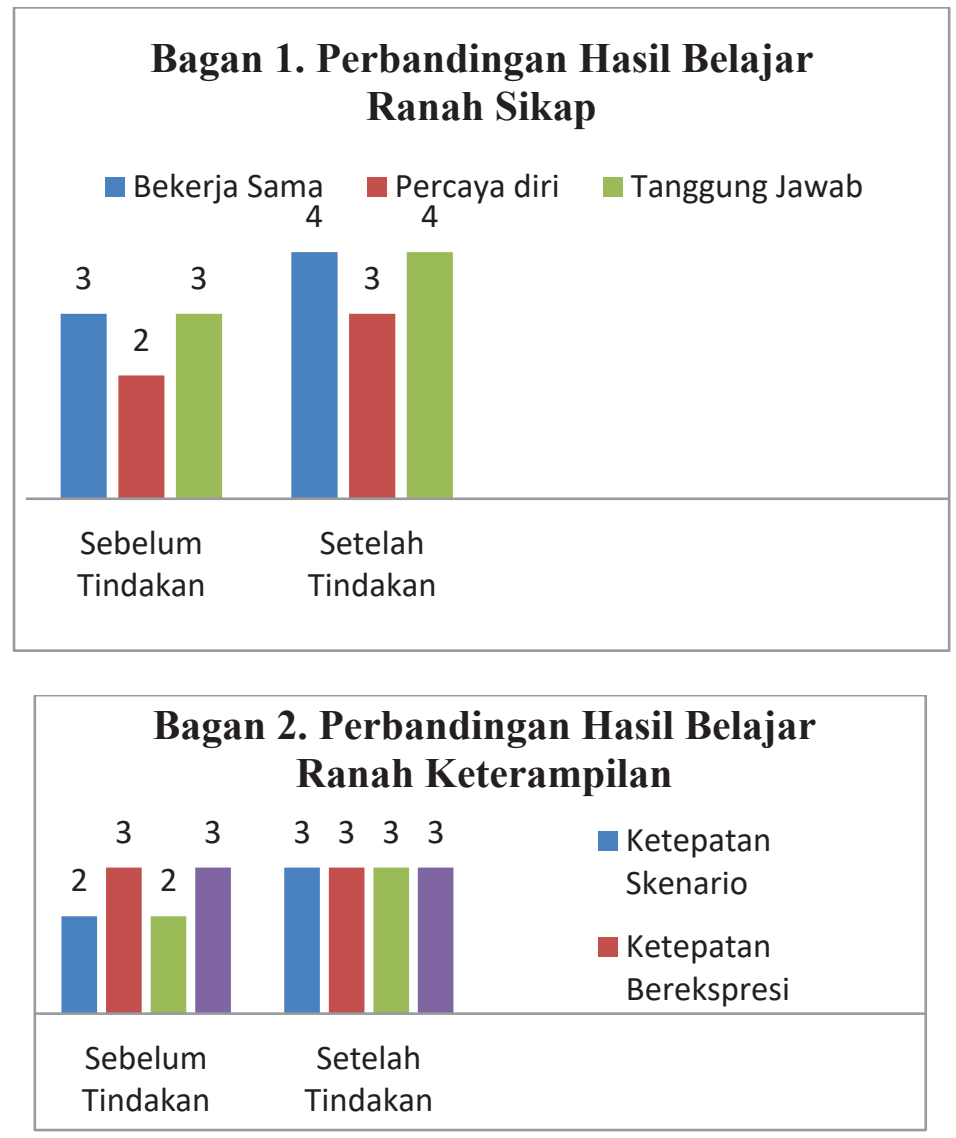

Selanjutnya berdasarkan observasi pelaksanaan pembelajaran setelah dilaksanakan tindakan, melalui rubrik penilaian terkait penilaian sikap siswa, diperoleh hasil bahwa rata-rata siswa mendapat predikat B (Baik) dengan rentang skor 3 pada sikap bekerja sama, percaya diri, dan tanggung jawab. Capaian hasil belajar pada ranah sikap diantaranya 1) Siswa mampu bekerjasama dalam kelompok dalam kegiatan bermain peran, 2) Siswa dengan percaya diri dalam menampilkan karakter tokoh yang diperankan, 3) Siswa menghafalkan teks dialog dengan baik sebagai indikator siswa bertanggungjawab terhadap tugas yang diberikan guru. Adapun perbandingan hasil belajar sebelum dengan setelah tindakan dalam ranah sikap ditampilkan dalam bagan 1 .
Terkait penilaian keterampilan secara klasikal siswa mencapai skor 3 dengan rata-rata 75 . Adapun penilaian dilakukan dengan mengunakan rumus:

$$
\begin{gathered}
\text { Penilaian }=\underline{\text { total skor siswa }} \times 100 \\
\text { total skor maksimal }
\end{gathered}
$$

Perbandingan hasil belajar dalam ranah keterampilan digambarkan dalam bagan 2 .

Capaian keterampilan yang mampu ditampilkan siswa yaitu: 1) ketepatan dalam menyampaikan skenario, 2) Ketepatan dalam menampilkan eksspresi sesuai keadaan pada skenario, 3) Kejelasan dalam pengucapan kata, 4) Keterampilan dalam menggunakan tinggi rendah nada sesuai pesan dalam skenario. 


\section{PEMBAHASAN}

Penerapan pembelajaran dengan model role playing yang telah dilakukan pada tahap tindakan diantaranya guru mengajukan pertanyaan pancingan tentang keberagaman individu (sintaks pertama pemanasan/ warming up). Selanjutnya guru menentukan siswa yang akan memainkan peran dan bertanya jawab terkait hal-hal yang belum dimengerti tentang peran yang akan dimainkan (sintaks kedua memilih pemain/partisipan). Dilanjutkan guru dan siswa mendiskusikan dimana dan bagaimana peran itu akan dimainkan (sintaks ketiga menata panggung). Selanjutnya guru menugaskan siswa yang tidak ikut berperan, bertugas sebagai pengamat (sintaks keempat menyiapkan pengamat/ observer). Siswa mulai bermain peran (sintaks kelima memainkan peran/ manggung). Guru dan siswa mendiskusikan permainan peran tadi dan melakukan evaluasi terhadap peranperan yang dilakukan (sintaks keenam diskusi dan evaluasi). Siswa yang bertugas sebagai pemain peran memerankan ulang adegan yang belum dipahami oleh pengamat (sintaks ketujuh memainkan peran ulang/manggung ulang). Selanjutnya siswa mendiskusikan tentang tokoh dalam kisah 5 Bersaudara untuk menemukan contoh keberagaman karakteristik individu berdasarkan sifat (sintaks kedelapan diskusi dan evaluasi kedua). Pada akhir kegiatan siswa sebagai pengamat mempresentasikan secara lisan mengenai tokoh dan sifat yang telah diperankan didepan kelas secara lisan, siswa diajak untuk berbagi pengalaman sebagai pemain peran dalam kisah 5 Bersaudara (sintaks kesembilan berbagi pengalaman dan kesimpulan). Jadi pene- rapan model pembelajaran role playing yang dilaksanakan sudah sesuai dengan sintaks dalam model pembelajaran role playing yang diyatakan oleh Huda (2015: 115) yaitu pemanasan, memilih peran, menata panggung, menyiapkan pengamat, memainkan peran, diskusi dan evaluasi, memainkan peran ulang, diskusi dan evaluasi kedua, serta berbagi pengalaman dan kesimpulan.

Penerapan model pembelajaran role playing mampu meningkatkan hasil belajar siswa dalam pembelajaran tematik kelas IV di SD Negeri Kecandran 01. Hal ini terlihat dari perbandingan hasil belajar pada kegiatan sebelum tindakan dengan setelah dilaksanakannya tindakan. Dalam ranah pengetahuan persentase ketuntasan meningkat menjadi 93\% dengan nilai rata-rata kelas 85. Penerapan model pembelajaran role playing mampu meningkatkan hasil belajar siswa diperkuat dengan data berdasarkan uji one sample $T$ test. Dimana berdasarkan perbandingan pada nilai probabilitas jika nilai sig (2-tailed) $>0,05$ maka Ho diterima, namun jika nilai sig (2tailed) $<0,05$ maka Ho ditolak dan diterima Ha. Adapun berdasarkan tabel hasil uji one sample $T$ test tercantum bahwa nilai sig (2tailed) yaitu ,00. Karena nilai probabilitas yaitu ,00<0,05, maka Ho ditolak. Jadi secara statistik dapat disimpulkan bahwa terjadi perbedaan hasil belajar siswa dalam ranah pengetahuan dengan model pembelajaran role playing setelah dilaksanakan tindakan dibanding dengan dengan rata-rata hasil belajar siswa sebelum dilaksanakan tindakan. Indikator terjadinya peningkatan hasil belajar dengan model role playing didukung pula dengan hasil penelitian terdahulu yang dilakukan oleh Djario, Mudzanatun, dan Enny Budi 
Wijaya (2012) dengan judul "Penerapan Model Pembelajaran Role playing Pada Mata Pelajaran IPA untuk Meningkatkan Hasil Belajar Siswa Kelas IV Semester I SD N Wonokerto 1 Karangtengah Demak Tahun Ajaran 2011/2012”. Peningkatan hasil belajar ditunjukkan pula pada rahan sikap dan keterampilan. Dimana capaian sikap siswa meningkat pada kategori baik dan capaian ranah keterampilan meningkat dari 62 menjadi 75. Peningkatan sikap sejalan dengan hasil penelitian yang dilakukan oleh Kirorim Baroroh dengan judul "Upaya Meningkatkan Nilai-Nilai Karakter Peserta Didik Melalui Penerapan Metode Role playing".

Jadi penerapan pembelajaran dengan model role playing yang dilakukan sesuai sintaks memberi ruang untuk keterpaduan capaian kompetensi. Kompetensi dalam ranah pengetahuan siswa mampu memperoleh ruang untuk belajar dari pengalaman secara langsung, dalam rahah sikap siswa mampu bekerjasama, menumbuhkan rasa percaya diri, dan bertanggung jawab, kemudian dalam ranah keterampilan siswa mampu mengembangkan keterampilan dalam ketepatan menyampaikan dan menampilkan ekspresi sesuai keadaan, kejelasan dalam pengucapan kata, serta keterampilan dalam menggunakan tinggi rendah nada sesuai pesan. Keterpaduan capaian kompetensi siswa dilatarbelakangi oleh pengalaman belajar yang dapat dieksplorasi dengan cara yang berbeda, dengan mengajarkan sikap dan melatih keterampilan bersesuaian dengan pernyataan Sinanglingtyas (2013:2) yang menyatakan bahwa model pembelajaran role playing berfungsi untuk 1) mengeksplorasi perasaan siwa, 2) mentransfer dan mewujudkan pandangan mengenai perilaku, nilai, dan persepsi siswa, 3) mengembangkan skill pemecahan masalah dan tingkah laku, 4) mengeksplorasi materi pembelajaran dengan cara yang berbeda.

Peningkatan hasil belajar melalui penerapan model pembelajaran role playing, membawa implikasi pada pentingnya penerapan model pembelajaran sesuai dengan sintaks dalam pelaksanaan pembelajaran tematik. Pentingnya penerapan model pembelajaran dalam mempengaruhi hasil belajar pada penilaian autentik sejalan dengan pendapat Mawardi (2014:107-108) yang menyatakan bahwa ruh implementasi kurikulum 2013 adalah pembelajaran yang dirancang dengan seksama, berdasarkan pengorganisasian materi dilakukan dengan menggunakan model tematik integratif, disinergikan dengan model-model pembelajaran inovatif, dan dilakukan penilaian dengan model penilaian autentik.

Adapun penentuan penerapan model pembelajaran role playing sesuai sintaks dan hasil belajar sebagai variabel dalam penelitan tindakan yang dilaksanakan, sesuai dengan pernyataan Mawardi (2014:120) dimana variabel penelitian tindakan yang diamati dan diukur minimal memuat dua variabel, yaitu proses pembelajaran sesuai dengan sintaks model yang dipilih dan variabel dampak (hasil belajar).

Selain itu model pembelajaran role playing dapat menumbuhkan antusias siswa dalam belajar. Hal ini terlihat dari besarnya peran dan antusias peserta didik dalam mengikuti kegiatan pembelajaran dengan model role playing seperti memiliki kemauan untuk menghafalkan teks dialog, membawa alat peraga dalam bermain peran, 
dan bekerja sama dalam memainkan peran. Hal ini bersesuaian dengan pendapat Setiawati (2011:231) yang menyatakan role playing sebagai suatu model pembelajaran interaksi sosial yang menyediakan kesempatan kepada siswa untuk melakukan kegiatan-kegiatan belajar secara aktif melalui personalisasi dengan cara memberikan peran-peran tertentu kepada siswa.

Akhirnya dengan melakukan perbandingan hasil sebelum dan setelah dilaksanakannya tindakan, serta menganalisis dengan tinjauan pustakan/penelitian yang relevan diperoleh bahwa kekuatan dalam penelitian ini yaitu terbukti mampu meningkatkan hasil belajar siswa pada pembelajaran tematik yang mencakup tiga ranah yaitu pengetahuan, sikap dan keterampilan. Adapun kelemahan dalam penelitian ini yaitu perlunya pengaturan kelas yang baik, membutuhkan persiapan perencanaan dan waktu yang matang dari guru. Sedangkan peluang yang muncul dari hasil penelitian ini yaitu model pembelajaran role playing dapat diterapkan pada tingkatan kelas lain tidak hanya kelas IV dengan menyesuaikan KD atau pengalaman belajar yang sesuai dengan sintaks dalam model pembelajaran role playing. Ancaman dari pelaksanaan penelitian ini yaitu siswa yang memiliki rasa kurang percaya diri memiliki kendala dalam menampilkan permainan peran. Namun kendala ini dapat diatasi dengan dukungan dan pengarahan dari guru secara personal, serta adanya dukungan dari teman-teman satu kelompok.

\section{SIMPULAN}

Berdasarkan hasil penelitian dan pembahasan, dapat di simpulkan bahwa penerapan model pembelajaran role playing sesuai dengan sintaks/langkah kegiatan dapat meningkatkan hasil belajar siswa pada pembelajaran tematik. Hal ini dibuktikan dengan peningkatan hasil belajar pada ranah pengetahuan dari persentase ketuntasan 48\% dengan rata-rata kelas 67 menjadi 93\% dengan rata-rata kelas 85 . Dalam ranah sikap rata-rata siswa mampu mencapai predikat B (Baik) dari predikat C (Cukup). Dalam ranah keterampilan hasil belajar meningkat dari rata-rata 62 menjadi 75. Terjadinya peningkatan hasil belajar dalam tiga ranah penilaian pada kurikulum 2013 yaitu pengetahuan, sikap dan keterampilan sehingga penelitian ini dianggap berhasil. Berdasarkan hasil penelitian terdapat beberapa saran diantaranya, bagi guru penerapan role playing sesuai dengan sintaks/langkah kegiatan terbukti mampu meningkatkan hasil belajar siswa dalam tiga ranah, untuk itu pelaksanaan proses pembelajaran sesuai dengan sintaks dalam model pembelajaran yang digunakan perlu dijadikan acuan. Adapun bagi kepala sekolah pembelajaran dengan model role playing ddigunakan sebagai bahan masukan dalam pembinaan kepada guru dalam pembelajaran tematik kurikulum 2013.

\section{DAFTAR PUSTAKA}

Arikunto, Suharsimi. 2012. Penelitian Tindakan Kelas. Jakarta: Bumi Akasara.

Baroroh, Kiromim. 2011. Upaya Meningkatkan Nilai-Nilai Karakter Peserta Didik Melalui Penerapan Metode Role playing. Jurnal Ekonomi \& Pendidikan, 8 (2):149163. 
Djario, dkk. 2012. Penerapan Model Pembelajaran Role playing Pada Mata Pelajaran IPA untuk Meningkatkan Hasil Belajar Siswa Kelas IV Semester I SD N Wonokerto 1 Karangtengah Demak Tahun Ajaran 2011/2012. Jurnal Pendidikan PGRI Semarang, 2 (1): 12-22.

Direktorat Pembinaan Sekolah Dasar. 2016. Panduan Teknis Pembelajaran dan Penilaian di Sekolah Dasar. Jakarta: Kementerian Pendidikan dan Kebudayaan.

Hamalik, Oemar. 2014. Proses Belajar Mengajar. Jakarta: Bumi Aksara.

Huda, Miftahul. 2015. Model-Model Pengajaran dan Pembelajaran. Yogyakarta: Pustaka Belajar.

Kemendikbud. 2016. Panduan Penilaian untuk Sekolah Dasar. Jakarta: Kementerian Pendidikan dan Kebudayaan.

Kunandar. 2014. Penilaian Autentik. Jakarta: PT Raja Grafindo Persada.

Mawardi. 2014. Pemberlakuan Kurikulum SD/MI Tahun 2013 dan Implikasinya Terhadap Upaya Memperbaiki Proses Pembelajaran Melalui PTK. Scholaria 4 (3):107120.

Mawardi. 2017. Merancang Model dan Media Pembelajaran. Scholaria 8 (1): 26-40.

Praturan Menteri Pendidikan dan Kebudayaan No. 23 Tahun 2016 Tentang Standar Penilaian Pendidikan.

Setiawati, Linda. 2011. Implementasi Role playing dalam Meningkatkan Hasil Belajar. Jurnal Ilmu Pendidikan Pedagogia hal 318-332.
Sinanglingtyas, Rahayu. 2013. Penerapan Metode Role playing untuk Meningkatkan Aktivitas dan Hasil Belajar Siswa Kelas V dalam Pembelajaran PKn Pokok Bahasan Bentuk-Bentuk Keputusan Bersama di SDN Tukum 01 Lumajang. Jurnal Pendidikan UNEJ, 1 (1): 1-5. Slameto. 2015. Rasional dan Elemen Perubahan Kurikulum 2013. Scholaria, 5 (1): 1-9.

Sudjana, Nana. 2006. Penilaian Hasil Proses Belajar Mengajar. Bandung: Remaja Rosdakarya.

Surat Keputusan Direktur Jendral Pendidikan Dasar dan Menengah Nomor.253/Kep.D/KR/2017

Tentang Penetapan Satuan Pelaksana Kurikulum 2013 Tahun 2017.

Yaumi, Muhammad. Muljono Damopoli. 2014 Action Research Teori, Model, dan Aplikasi. Jakarta: Kencana 